\title{
Water retaining polymer and fertilization in the implantation of Toona ciliata M. Roemer
}

\author{
Polímero hidrorretentor e adubação na implantação \\ de Toona ciliata M. Roemer
}

\begin{abstract}
Erick Martins Nieri ${ }^{1 *}$, Carlos Eduardo Siqueira Teixeira ${ }^{1}$, Lucas Amaral de Melo ${ }^{1}$, Diana Suzete Nunes da Silva', Matheus Santos Luz ${ }^{1}$ and Soraya Alvarenga Botelho'
\end{abstract}

\begin{abstract}
Resumo
O uso de polímero hidrorretentor e a disponibilidade de nutrientes são fatores que influenciam o estabelecimento e desenvolvimento das mudas em fase inicial de plantio. Avaliou-se o efeito do polímero hidrorretentor/hidrogel e a influência de doses de adubo na sobrevivência, crescimento e teores de nutrientes de Toona ciliata recém implantada. Utilizou-se o desenho experimental em esquema fatorial $2 \times 5$ (duas doses de hidrogel $\left(0 \mathrm{e} 400 \mathrm{ml} \mathrm{plt}^{-1}\right)$ e cinco combinações de adubação (nitrogênio $(\mathrm{N})$ : $\mathrm{NO}=0, \mathrm{~N} 1=62 \mathrm{e} \mathrm{N2}=124 \mathrm{~g} \mathrm{plt}^{-1}$; fósforo $(\mathrm{P})$ : $\mathrm{P0}=0, \mathrm{P} 1=75$ e P2 $=150 \mathrm{~g} \mathrm{plt}^{-1}$ e potássio $(\mathrm{K}): \mathrm{K} 0=0, \mathrm{~K} 1=62$ e K2 $=124 \mathrm{~g} \mathrm{plt}^{-1}$, nomeados da seguinte forma: NOP0K0, NOP1K0, N1P0K1, N1P1K1 e N2P2K2), em delineamento de blocos casualizados completos, com três repetições e cinco plantas por parcela em arranjo $3 \times 2 \mathrm{~m}$. Aplicou-se a concentração de $1 \mathrm{~g}$ de hidrogel para $400 \mathrm{ml}$ de água. Mensurou-se aos 60,120, 150 e 180 dias pós-plantio a sobrevivência, o diâmetro à altura do coleto e a altura total. A análise foliar foi realizada com base nos dados de crescimento apenas dos melhores tratamentos (N1P1K1 e N2P2K2) aos 180 dias. O hidrogel favoreceu a sobrevivência, mas não apresentou interação com as doses de adubo mineral testadas para a espécie. $O$ cedro australiano respondeu à aplicação de doses de NPK, e a dosagem máxima (N2P2K2) proporcionou maior incremento em diâmetro do coleto e altura de planta. A aplicação de nitrogênio e potássio foi eficiente para a espécie. A omissão de fósforo na implantação foi o fator mais limitante para o crescimento de Toona ciliata.
\end{abstract}

Palavras-chave: Silvicultura, Hidrogel, Cedro australiano, NPK.

\begin{abstract}
The use of water retaining polymer and the nutrients availability are factors that influence the establishment and development of seedlings in the initial phases of planting. The effect of water retaining/hydrogel polymer and the influence of fertilization dosages were evaluated on survival, growth and nutrient contents of Toona ciliata in the field implantation. The used experimental design was a $2 \times 5$ factorial design (two hydrogel doses $\left(0\right.$ and $\left.400 \mathrm{ml} \mathrm{plt}^{-1}\right)$ and five fertilization combinations (nitrogen $(\mathrm{N})$ : N0 $=0, \mathrm{~N} 1=62$, and $\mathrm{N} 2=124 \mathrm{~g} \mathrm{plt}^{-1}$; phosphorus $(\mathrm{P}): \mathrm{P} 0=0, \mathrm{P} 1=75$, and $\mathrm{P} 2=150 \mathrm{~g} \mathrm{plt}^{-1}$, and potassium $(\mathrm{K}): \mathrm{K} 0=0, \mathrm{~K} 1=62$, and $\mathrm{K} 2$ = $124 \mathrm{~g} \mathrm{plt}^{-1}$, named as follows: NOP0K0, N1P1K1, N1P1K1, and N2P2K2), in a randomized complete block design with three replications and five plants per plot in $3 \times 2 \mathrm{~m}$ arrangement. The concentration of $1 \mathrm{~g}$ of hydrogel was applied to $400 \mathrm{ml}$ of water. The survival, root collar diameter and total height were measured at $60,120,150$, and 180 days after planting. The foliar analysis was performed based on the growth data only of the best treatments (N1P1K1 and N2P2K2) at 180 days. The hydrogel favored survival, but did not show interaction with the different fertilization levels tested for the species. The Australian red cedar responded to the application of dosages of NPK, and the maximum dosage (N2P2K2) provided a higher increase in root collar diameter and height. The application of nitrogen and potassium was efficient for this species. The omission of phosphorus at implantation was the most limiting factor for the growth of Toona ciliata.
\end{abstract}

Keywords: Forestry, Hydrogel, Australian red cedar, NPK.

\section{INTRODUCTION}

The adequate supply of water and nutrients contributes significantly to the productivity increase of forest stands. The use of water retaining polymers or hydrogels appears as an alternative to supply the water demand in the initial development phase of these plantations (CARVALHO et al., 2013; MILANI et al., 2017; NAVROSKI et al., 2016).

1. Forestry Department, Universidade Federal de Lavras - UFLA. Lavras / MG, Brazil. *Corresponding author: erickenieri@yahoo.com.br 
Nieri et al. - Water retaining polymer and fertilization in the implantation of

Toona ciliata M. Roemer

Water retaining polymers are valued products by their ability to gradually absorb and release water. The arrangement nature of the molecules gives the material a granular form when dried and, upon being hydrated, the granules dilate becoming gel particles (PREVEDELLO; BALENA, 2000).

When incorporated in the soil, the hydrogel allows higher retention of water and fertilizers, which are released more slowly to the plants depending on the absorption and release cycles. Moreover, due to its high cation exchange capacity, the product aids reducing nutrient leaching (BERNARDI et al., 2012; TAYLOR; HALFACRE, 1986). Other benefits can be observed with the use of water retaining polymer, such as reduction of water loss, reduction of costs with irrigation and replanting of seedlings, thus allowing a lower production cost (MILANI et al., 2017).

In a study on the growth of Corymbia citriodora seedlings due to the use of hydrogel and fertilization, Bernardi et al. (2012) verified a positive effect for the variables height and root collar diameter through the polymer use and that it can reduce the mulch and topdressing fertilization ( $\mathrm{N}$, P e K) by up to $40 \%$.

However, the use of the water retaining polymer should be carefully evaluated as there is a probability of adverse side effects. According to Peterson (2003), in cases with excess salts and nutrients in the soil, the polymer addition little contributes to the growth and development of plants, and may even become harmful. Such effect was observed by Vichiato, Vichiato e Silva (2004), who noticed an excess of nutrients in the substrate of seedlings due to the high concentration of fertilizers and salts promoted by the high water retention by the hydrogel, which hindered their development.

For reduce losses in the field and the development of seedlings, should know/understand the factors affecting the interaction of nutrients with the use of hydrogel. In this context, there are few studies in the literature involving nutrient absorption and the nutritional requirements and the required conditions regarding the water factors for Toona ciliata. This is popularly known as Australian red cedar, has shown to be promising mainly due to its adaptability to Brazilian edaphic climatic conditions, rapid growth and quality of produced wood (MORETTI et al., 2011; NAVROSKI et al., 2017).

In this sense, it is noted the need for studies that seek to evaluate the real effects of water retaining polymer and fertilization in the phase of forest implantation for forestry species, especially those that are considerably promising, such as the Australian red cedar, since the results found in the present study can possibly be used as parameters/references to meet this need.

The aim of this study was to evaluate the effect of the water retaining polymer and fertilization dosages on the survival, growth and nutrient contents of $T$. ciliata during the implantation phase.

\section{MATERIAL AND METHODS}

The experiment was installed in December 2016 in a place under high altitude tropical climate with mild summers, wet mesothermic type Cwb, according to Köppen classification, where the region has a temperature of the hottest month below $22^{\circ} \mathrm{C}$ and average between 18 and $19^{\circ} \mathrm{C}$. The mean annual rainfall is $1511 \mathrm{~mm}$, ranging from $16.9 \mathrm{~mm}$ in the driest month to $293.9 \mathrm{~mm}$ in the month with the highest rainfall (ALVARES et al., 2013).

After sampling of the area, the experimental site was classified as dystrophic Red Latosol (Oxisol) of clayey texture (66\% clay) (EMBRAPA, 2013), and a composite sample was collected for chemical analysis (Table 1).

The Australian red cedar clonal seedlings had the following quality standards: a well-structured root system (new roots, allowing its removal from the stem without undoing the clod), height (25 to $30 \mathrm{~cm})$, root collar diameter ( 5 to $6 \mathrm{~mm}$ ) and seedlings hardening.

For the conditioning of the experimental area, the control of leafcutter ants (periodically), cleaning of the area through a $4 \times 2$ tractor ( $4 \times 2$ FWD) with cutting grid, weed control (periodically) and soil preparation by means of scarification with $(4 \times 2$ FWD) were performed. The Australian red cedar hasn't recommended soil correction, planting and coverage fertilization consolidated in the literature. In this case, the recommendation used was that described for Eucalyptus. According to the chemical analysis (Table 1) and as described in the recommendation of Barros and Novais (1999), it wasn't necessary to perform to correct the soil.

The used treatments were two doses of hydrogel and five levels of fertilization. The hydrogel doses correspond to 0 and $400 \mathrm{ml}$ per plant, being the concentration used of $1 \mathrm{~g}$ of hydrogel to $400 \mathrm{ml}$ of water and its application in a pit, incorporating the solution to the soil. These quantities are in 
Table 1 - Summary of soil chemical analysis (layer of 0-20 cm) of the experimental area.

\begin{tabular}{|c|c|c|c|c|c|c|c|c|c|c|c|}
\hline \multirow{2}{*}{$\begin{array}{l}\text { Depth } \\
(\mathrm{cm})\end{array}$} & \multirow{2}{*}{$\begin{array}{c}\mathrm{pH} \\
(\mathrm{KCl})\end{array}$} & \multirow{2}{*}{$\frac{\text { MO }}{\text { dag kg-1 }^{-1}}$} & $\mathrm{~K}$ & $\mathbf{P}$ & $\mathrm{Ca}$ & $\mathrm{Mg}$ & $\mathrm{Al}$ & $\mathrm{H}+\mathrm{Al}$ & $\mathbf{T}$ & V & $m$ \\
\hline & & & \multicolumn{2}{|c|}{$\mathrm{mg} \mathrm{dm}^{-3}$} & \multicolumn{4}{|c|}{$\mathrm{cmol} \mathrm{dm}^{-3}$} & \multicolumn{3}{|c|}{$\%$} \\
\hline $0-20$ & 5.4 & 1.35 & 37.02 & 1.22 & 1.36 & 0.3 & 0.1 & 2.27 & 4.02 & 43.65 & 5.41 \\
\hline
\end{tabular}

*MO: organic matter; T: cation exchange capacity at $\mathrm{pH} 7.0$; V: base saturation index; m: aluminum saturation index.

agreement with the product manufacturer, who recommends $1 \mathrm{~kg}$ of water retaining polymer for 400 liters of water, which is equivalent to $1 \mathrm{~g}$ of polymer per plant.

The fertilization levels correspond to the combination of doses of $\mathrm{N}$ : N0 $=0, \mathrm{~N} 1=62$, and $\mathrm{N} 2=124 \mathrm{~g} \mathrm{plt}^{-1}, \mathrm{P}: \mathrm{P} 0=0, \mathrm{P} 1=75$, and $\mathrm{P} 2=150 \mathrm{~g} \mathrm{plt}^{-1}$, and $\mathrm{K}: \mathrm{K} 0=0, \mathrm{~K} 1=62$, and $\mathrm{K} 2=124 \mathrm{~g} \mathrm{plt}^{-1}$, being named as follows: NOP0K0, NOP1K0, N1P0K1, N1P1K1, and N2P2K2. These treatments based on the recommendation for eucalyptus with $30 \mathrm{~m}^{3} \mathrm{ha}^{-1}$ year-1 $^{-1}$ production to obtain the doses (BARROS; NOVAIS, 1999) and according to the Moro et al. (2014) for the combinations N, P, and K. The simple superphosphate $\left(18 \% \mathrm{P}_{2} \mathrm{O}_{5}\right)$ and a NPK formulate of 20:00:20 (20\% $\mathrm{N}$ and $\left.20 \% \mathrm{~K}_{2} \mathrm{O}\right)$ were used urea and potassium chloride as sources of these nutrients.

Phosphorus doses applied in a hole during the plantation. Nitrogen and potassium doses applied to the crown projection area, $15 \mathrm{~cm}$, at 60 days post-planting on before precipitation.

The experimental design was used in a 2 x 5 factorial design (two hydrogel doses and five fertilization combinations) in a randomized complete block design with three replications and five seedlings per plot, in a $3 \times 2 \mathrm{~m}$ arrangement. At 60, 120, 150 and 180 days after planting, the survival, root collar diameter and total plant height were evaluated.

After 180 days post-planting from the growth results, freshly mature leaves of the upper third of plants were collected, as suggested for eucalyptus by Barros and Novais (1999). This collection was performed in plants from treatments considered as better based on the growth data, being these samples composed of the treatments $\mathrm{N} 1 \mathrm{P} 1 \mathrm{~K} 1$ and $\mathrm{N} 2 \mathrm{P} 2 \mathrm{~K} 2$, which were processed and analyzed according to the Manual of Mineral Nutrition of Plants for the nutrients $\mathrm{N}, \mathrm{P}, \mathrm{K}, \mathrm{Ca}, \mathrm{Mg}, \mathrm{S}, \mathrm{Mn}, \mathrm{Zn}$, $\mathrm{B}, \mathrm{Cu}$ and $\mathrm{Fe}$ (MALAVOLTA, 2006).

Survival and growth data were submitted to normality analysis of errors by the Shapiro-Wilk test at 5\% error probability, using the R statistical software (R CORE TEAM, 2016). Afterwards, the analysis of variance was performed and, when significant, the Scott-Knott clustering test was performed at 5\% error probability (FERREIRA, 2011).

\section{RESULTS AND DISCUSSION}

In Table 2 are the results of analysis of variance for the survival variable of the clonal changes of T. ciliata at $60,120,150$ and 180 days post-planting. It is possible to verify that there was no significant interaction between the dose effects of fertilization and hydrogel.

In Table 2, it was verified that there was also no significant difference among treatments regarding the effects of fertilization doses for survival. However, it was observed that the presence of the water retaining polymer provided superior survival when compared to the absence of polymer treatment

Table 2 - Summary of the analysis of variance for survival of T. ciliata seedlings at 60, 120, 150 and 180 days post-planting, as a function of the use of hydrogel and implantation fertilization.

\begin{tabular}{|c|c|c|c|c|c|}
\hline \multirow{2}{*}{ SV 1} & \multirow{2}{*}{$\mathrm{DF}^{2}$} & \multicolumn{4}{|c|}{ Mean square } \\
\hline & & 60 days & 120 days & 150 days & 180 days \\
\hline BLOCK & 2 & $0.3230 \mathrm{~ns}$ & $0.0098 \mathrm{~ns}$ & $0.0197 \mathrm{~ns}$ & $0.0197 \mathrm{~ns}$ \\
\hline HYDROGEL & 1 & $0.7470^{*}$ & $0.9492^{* *}$ & $0.0162^{*}$ & $0.0162^{*}$ \\
\hline DOSE & 4 & $0.2583 n s$ & $0.2306 n s$ & $0.0852 \mathrm{~ns}$ & $0.0852 \mathrm{~ns}$ \\
\hline HYDROGEL*DOSE & 4 & $0.0699 \mathrm{~ns}$ & $0.1751 \mathrm{~ns}$ & $0.1278 \mathrm{~ns}$ & $0.1278 \mathrm{~ns}$ \\
\hline ERROR & 18 & 0.1165 & 0.0961 & 0.1044 & 0.1044 \\
\hline $\mathrm{CV}^{3}(\%)$ & - & 30.43 & 35.18 & 37.00 & 37.00 \\
\hline$M^{4}(\%)$ & - & 76.00 & 57.00 & 56.70 & 56.70 \\
\hline
\end{tabular}

'Source of variation; ${ }^{2}$ Degree of freedom; ${ }^{3}$ Cofficient of variation; ${ }^{4}$ General mean; ${ }^{\text {ns }}$ Not significant at $5 \%$ error probability; $* *$ Significant at I\% error probability, *Significant at $5 \%$ error probability. 
Nieri et al. - Water retaining polymer and fertilization in the implantation of

Toona ciliata M. Roemer

in all the evaluated periods (Table 3), since the treatment with presence of the polymer showed $85 \%$ survival at 60 days, $69 \%$ at 120 days and $67 \%$ at 150 and 180 days, while the treatments with absence showed $67 \%, 45 \%, 45 \%$, and $45 \%$ respectively.

Table 3 - Mean survival of T. ciliata seedlings at 60,120, 150 and 180 days post-planting.

\begin{tabular}{ccccc}
\hline Hydrogel doses & 60 days & 120 days & 160 days & 180 days \\
\hline Presence of the hydrogel & $85 \mathrm{a}$ & $69 \mathrm{a}$ & $67 \mathrm{a}$ & $67 \mathrm{a}$ \\
Absence of the hydrogel & $67 \mathrm{~b}$ & $45 \mathrm{~b}$ & $45 \mathrm{~b}$ & $45 \mathrm{~b}$ \\
\hline
\end{tabular}

* Averages followed by the same letter on the columns do not differ among themselves by F-test at $5 \%$ error probability.

The scalding of the stem base, possibly, influenced the mortality of $15 \%$ of the best treatment. This scalding was observed in the field and results from the elevation of the temperature of the soil by the solar rays, which factor promotes the interruption at the translocation of water and sap and, consequently, the death of the plant (VILELA, 2018).

The mean rainfall for the months of January $(158 \mathrm{~mm}$ ) and February (63 mm) of 2017 (Figure 1) were lower than the average of January $(280 \mathrm{~mm})$ and February $(200 \mathrm{~mm})$ of the historical series of 1961-1990 (INMET, 2018). This, possibly, favored the influence of the water retaining polymer on the survival of the seedlings, since this period is considered critical in relation to the establishment of seedlings in the field.

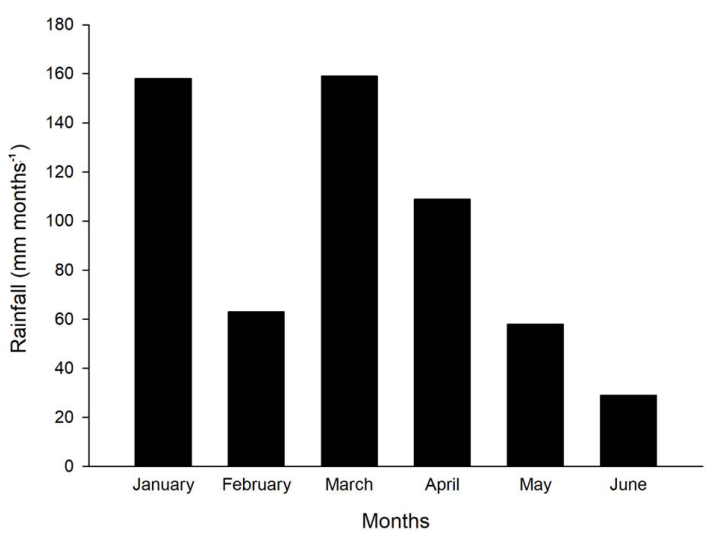

Figure 1 - Monthly rainfall in Lavras-MG, during January, February, March, April, May, and June the 2017.

Possibly, the results strengthen the hypothesis that the hydrogel provides higher soil moisture in the establishment period of seedlings in the field, since the seedlings show a small root system and with little water and nutrient absorption efficiency at that moment. Souza et al. (2010) point out that in the implantation phase, the Australian red cedar is highly responsive to the amount of water available and therefore the application of the water retaining polymer at the planting stage is vital in order to obtain high survival. In this respect, Klein et al. (2016) recommend the use of water retaining polymers for planting the species.

In a study evaluating the survival and growth of Jatropha curcas L. as a function of growing season and hydrogel use at the experimental area with average annual rainfall of $1500 \mathrm{~mm}$ and Oxisol of clayey texture, Dranski et al. (2013) also verified a higher survival of seedlings with the presence of water retaining polymer when the planting was performed in the summer, such as the case of the present study.

When evaluating the root collar diameter and height (Table 4), there was no significant interaction between fertilization levels and hydrogel application. When studying the main effects, there was no significant difference among the hydrogel levels, but there was an average difference among the fertilization levels (Tables 4 and 5).

As there is no interaction between the hydrogel factors and fertilization, it can be inferred that the water retaining polymer did not maximize the nutrient availability for the species, being this fact possibly linked to the edaphoclimatic conditions of the experimental site. However, in studies performed by Bernardi et al. (2012) and Bartieres et al. (2016), it was observed that the association of 
Table 4 - Summary of the analysis of variance for the root collar diameter and height of $T$. ciliata seedlings at $60,120,150$ and 180 days of age, as a function of the use of hydrogel and implantation fertilization.

\begin{tabular}{|c|c|c|c|c|c|}
\hline \multirow{2}{*}{$\mathbf{S V}^{1}$} & \multirow{2}{*}{$\mathrm{DF}^{2}$} & \multicolumn{4}{|c|}{ Mean square } \\
\hline & & 60 days & 120 days & 150 days & 180 days \\
\hline \multicolumn{6}{|c|}{ Root collar diameter } \\
\hline BLOCK & 2 & $0.4427 n s$ & $0.0324 n s$ & $2.3998 n s$ & $2.8355 \mathrm{~ns}$ \\
\hline HYDROGEL & 1 & $0.7806 n s$ & $0.0084 n s$ & $2.7871 \mathrm{~ns}$ & $0.1468 \mathrm{~ns}$ \\
\hline DOSE & 4 & $2.5218^{*}$ & $91.4499^{*}$ & $126.6678^{*}$ & $148.6516^{*}$ \\
\hline HYDROGEL*DOSE & 4 & $0.8414 \mathrm{~ns}$ & $7.6235 \mathrm{~ns}$ & $9.8292 \mathrm{~ns}$ & $6.1094 \mathrm{~ns}$ \\
\hline ERROR & 18 & 0.3433 & 4.1856 & 3.6191 & 3.6426 \\
\hline $\mathrm{CV}^{3}(\%)$ & - & 6.48 & 11.81 & 9.27 & 8.28 \\
\hline $\mathrm{M}^{4}(\mathrm{~cm})$ & - & 9.13 & 17.33 & 20.52 & 23.05 \\
\hline \multicolumn{6}{|c|}{ Height } \\
\hline BLOCK & 2 & $19.8993 n s$ & $7.902 \mathrm{~ns}$ & $202.6622 n s$ & $78.9262 \mathrm{~ns}$ \\
\hline HYDROGEL & 1 & $4.1849 \mathrm{~ns}$ & $36.0803 n s$ & $52.9214 n s$ & $184.0045 \mathrm{~ns}$ \\
\hline DOSE & 4 & $132.2549^{*}$ & $3698.8189^{*}$ & $4843.8012^{*}$ & $6649.2579^{*}$ \\
\hline HYDROGEL*DOSE & 4 & $25.5348 \mathrm{~ns}$ & $278.7298 n s$ & $401.9666 n s$ & $482.4007 \mathrm{~ns}$ \\
\hline ERROR & 18 & 25.3607 & 101.2623 & 177.6129 & 321.3508 \\
\hline $\mathrm{CV}^{3}(\%)$ & - & 11.68 & 10.36 & 11.62 & 13.69 \\
\hline $\mathrm{M}^{4}(\mathrm{~m})$ & - & 42.26 & 97.10 & 114.68 & 130.91 \\
\hline
\end{tabular}

'Source of variation; ${ }^{2}$ Degree of freedom; ${ }^{3}$ Cofficient of variation; ${ }^{4}$ General mean; ${ }^{n}$ Not significant at $5 \%$ error probability; $*$ Significant at $5 \%$ error probability.

Table 5 - Root collar diameter and height of T. ciliata seedlings at 60, 120, 150 and 180 days post-planting, depending on the fertilization levels.

\begin{tabular}{|c|c|c|c|c|}
\hline \multirow{2}{*}{$\begin{array}{c}\text { Fertilization } \\
\text { levels }\end{array}$} & \multicolumn{4}{|c|}{ Days after planting } \\
\hline & 60 & 120 & 150 & 180 \\
\hline \multicolumn{5}{|c|}{ Root collar diameter (cm) } \\
\hline NOPOKO & $8.88 \mathrm{~b}$ & $13.48 \mathrm{c}$ & $16.11 \mathrm{c}$ & $17.68 \mathrm{c}$ \\
\hline N0P1K0 & 9.88 a & $18.83 \mathrm{~b}$ & $22.55 \mathrm{~b}$ & $25.51 \mathrm{~b}$ \\
\hline N1P0K1 & $8.17 \mathrm{~b}$ & $13.13 \mathrm{c}$ & $15.29 \mathrm{c}$ & $17.73 \mathrm{c}$ \\
\hline N1P1K1 & $9.31 \mathrm{a}$ & $19.05 \mathrm{~b}$ & $22.82 b$ & $26.12 b$ \\
\hline N2P2K2 & $9.44 \mathrm{a}$ & $22.16 \mathrm{a}$ & $25.83 \mathrm{a}$ & $28.19 \mathrm{a}$ \\
\hline \multicolumn{5}{|c|}{ Height (m) } \\
\hline NOPOKO & $37.80 \mathrm{~b}$ & $70.48 \mathrm{c}$ & $84.91 \mathrm{c}$ & $97.11 \mathrm{c}$ \\
\hline N0P1K0 & $47.32 \mathrm{a}$ & $107.41 \mathrm{~b}$ & $125.56 \mathrm{~b}$ & $138.08 \mathrm{~b}$ \\
\hline N1P0K1 & $36.73 \mathrm{~b}$ & $71.97 \mathrm{c}$ & $86.53 \mathrm{c}$ & $96.11 \mathrm{c}$ \\
\hline N1P1K1 & 44.75 a & $108.82 b$ & $125.42 b$ & $150.83 \mathrm{~b}$ \\
\hline N2P2K2 & $44.70 \mathrm{a}$ & $126.81 \mathrm{a}$ & 150.97 a & $171.81 \mathrm{a}$ \\
\hline
\end{tabular}

* Averages followed by the same letter on the columns do not differ among themselves by Scott-Knott test at $5 \%$ error probability.

water retaining polymer and the fertilization increased height and root collar diameter of Corymbia citriodora seedlings and clones of hybrids from Eucalyptus grandis $x$ Eucalyptus camaldulensis implanted in commercial substratum and in Red Argisol of sandy texture, respectively.

These results demonstrate that sandy soils present a greater intensity of nutrient leaching (WERLE et al., 2008) and the use of water retaining polymer, probably, provides this soil greater moisture, water retention and nutrients for the absorption of the plant once that sandy textured soils have a lower cation exchange capacity (CTC) than clayey soils. According to Idrobo et al., (2010), the use of hydrogel in soils with high natural levels of drainage and nutrient-poor are considered complementary (IDROBO et al., 2010).

Regarding the effect of fertilization, it can be noted that phosphorus is essential for the growth of cedar plants and that, even with application of $\mathrm{N}$ and $\mathrm{K}$, the seedlings showed inferior performance in the absence of $\mathrm{P}$ when compared to those that received it (Table 5). The importance of phosphorus is also related to the low level found in the soil initial, below the critical level (BARROS; NOVAIS 1999), and with the subsequent availability to the soil to supply the demand the P for the species. Malavolta (2006) cites the phosphorus functions as a component of plasmalemma and tonoplast lipids, which are the obligatory passage of nutrients in the absorption process, both in root and leaf, storage of energy in photosynthesis and respiration, use of energy for protein synthesis reactions, 
Nieri et al. - Water retaining polymer and fertilization in the implantation of

Toona ciliata M. Roemer

biological fixation of nitrogen, transfer of genotypic plant characters with its external manifestations that depend on the environment.

At 60 days, it was verified that the seedlings of treatments in which the phosphorus had been applied in the planting fertilization showed averages the Root collar diameter and height superiors to the seedlings from other treatments. These results show the importance of nutrient phosphorus in the initial growth phase of this species, as already explained for innumerable other forest species.

Furthermore, it was observed that treatments with absence of phosphorus in all measurements showed lower growth seedlings when compared to treatments in which phosphorus was applied in planting fertilization, and the application of this nutrient is fundamental for the implantation of Australian red cedar.

Moretti et al. (2011) found that the omission of phosphorus was limiting to the growth of T. ciliata, as found in the present study. However, Da Ros et al. (2016) analyzed the initial growth of T. ciliata and verified that omitting phosphorus from fertilization, the growth in height, root collar diameter and diameter at breast height was not influenced. However, contrary to what was found in the present study, when nitrogen was withdrawn from fertilization, a reduction for growth in height and root collar diameter.

Rocha et al. (2013) analyzed the growth of eucalyptus seedlings under different dosages of phosphorus and concluded that this element positively influenced plant growth, but emphasize the importance of using a correct nutrient dosage.

In this regard, Resende et al. (1999) also point out that in the initial development phase of forestry species, the responsiveness to the phosphorus supply is different, depending on the successional group and the studied species, since pioneer species respond more quickly to the nutrient supply. As the Australian red cedar is considered a pioneer successional stage (BUDOWSKI, 1965), it is noted the high efficiency of nutrient use, showing higher increases in root collar diameter when the phosphorus was available in the planting fertilization.

It is clear that at 60 days after planting, the treatments that had phosphorus application showed seedlings with averages of height and diameter superior to the other treatments. This result, probably, evidence a more developed root system, that is, explains the higher response to $\mathrm{N}$ and $\mathrm{K}$ coverage fertilization. At this moment, the topdressing fertilization was performed, which demonstrated significant results at 120 days. Thus, at 120,150 and 180 days after planting, the treatment containing the maximum dosage of three nutrients (N2P2K2) showed seedlings with higher averages. Similar results were found by De Marco et al. (2013), which verified a higher growth rate under dosages of $9 \mathrm{~kg} \mathrm{~m}^{-3}$ of NPK (9:33:12) for T. ciliata in tubes, but they affirm that very high dosages compromise the health and survival of the seedlings.

Souza et al. (2010) recommend that, for T. ciliata, two nitrogen and potassium topdressing fertilizations are performed, one in the first and the other in the second crop year, depending on the location of the property and, in particular, the condition of the land.

Navroski et al. (2016) analyzed the use of hydrogel in the production of Eucalyptus dunnii seedlings and verified that the height and diameter at breast height $(\mathrm{DBH})$ of plants were inferior in the presence of hydrogel and when applying more than $50 \%$ of the recommended fertilizer dose, i.e., they did not observe influence of the polymer applied together with the recommended total dose of fertilizer for the seedling growth. However, in the present study, for these variables, the effect of different nitrogen, phosphorus and potassium dosages showed a significant difference in all the evaluations performed in T. ciliata seedlings.

According to Barros and Novais (1999), a correct dosage of fertilizer is essential in order to obtain maximum productivity without generating toxicity to the plants. It can be verified in this study, possibly, that the correct application at the right time of the three nutrients (NPK) was efficient, both for the root collar diameter and for the plant height of T. ciliata seedlings.

Due to the high initial demand for phosphorus by perennial plants, the scarcity of this nutrient in the solution of Brazilian soils and the ease of being adsorbed in the forms not available to the plants, it is necessary to apply a soluble source of this element in a localized way on the pit, in the planting season, aiming at high productivity (BARROS; NEVES; NOVAIS., 2005).

According to Paiva et al. (2011), application of nitrogen and potassium should be performed between 40 and 60 days after planting, preferably with moist soil and partitioning its application in order to avoid leaching loss. If the fertilization was performed in dry season, the fertilizer must 
be applied in order to incorporate it in the soil in order to avoid nitrogen losses by volatilization. Furthermore, it is emphasized that the fertilization of $\mathrm{N}$ and $\mathrm{K}$ should be done when the seedlings show the well-developed root system, so that they can absorb these nutrients more efficiently.

In relation to leaf analysis, the external concentration of ions is one of the factors that affect root ion absorption (MARSCHNER, 2012). In Table 6, the nutrient content (N, P, K, Ca, Mg, S, Mn, Zn, B, Cu e Fe) of $T$. ciliata leaves can be observed for the treatments considered better based on the growth at 180 days post-planting, and these values may possibly be used as reference for the species.

Table 6 - Nutrient content in leaves of T. ciliata for the treatments considered better based on the growth at 180 days post-planting, as a function of the implantation fertilization.

\begin{tabular}{|c|c|c|c|c|c|c|c|c|c|c|c|}
\hline \multirow{2}{*}{ Treatments } & $\mathbf{N}$ & $\mathbf{P}$ & $\mathrm{K}$ & $\mathrm{Ca}$ & $\mathrm{Mg}$ & S & Mn & $\mathrm{Zn}$ & B & $\mathrm{Cu}$ & $\mathrm{Fe}$ \\
\hline & \multicolumn{6}{|c|}{$\mathrm{g} \mathrm{kg}^{-1}$} & \multicolumn{5}{|c|}{$\mathrm{mg} \mathrm{kg}^{-1}$} \\
\hline N1P1K1 & 28.40 & 1.55 & 18.10 & 12.50 & 1.30 & 1.55 & 17.75 & 21.70 & 17.00 & 9.20 & 261.20 \\
\hline N2P2K2 & 27.95 & 1.55 & 19.30 & 6.70 & 1.35 & 1.45 & 17.85 & 17.35 & 18.10 & 9.25 & 136.90 \\
\hline Average & 28.18 & 1.55 & 18.70 & 9.60 & 1.33 & 1.50 & 17.80 & 19.53 & 17.55 & 9.23 & 199.05 \\
\hline
\end{tabular}

$\mathrm{NI}: 62 \mathrm{~g} \mathrm{plt}^{-1} ; \mathrm{N2}$ : $124 \mathrm{~g} \mathrm{plt}^{-1} ; \mathrm{PI}: 75 \mathrm{~g} \mathrm{plt}^{-1} ; \mathrm{P} 2: 150 \mathrm{~g} \mathrm{plt}^{-1} ; \mathrm{KI}: 62 \mathrm{~g} \mathrm{plt}^{-1}$ and $\mathrm{K} 2: 124 \mathrm{~g} \mathrm{plt}^{-1}$. Sources: simple superphosphate $\left(18 \% \mathrm{P}_{2} \mathrm{O}_{5}\right)$ and $\mathrm{NPK}$ formulate of 20:00:20 (20\% N and $\left.20 \% \mathrm{~K}_{2} \mathrm{O}\right)$ were used potassium chloride as sources of these nutrients.

It is observed that the nitrogen, phosphorus and potassium contents are above the critical level for eucalyptus (N: 14-16; P: 1-1.2; K: 10-12 $\mathrm{g} \mathrm{kg}^{-1}$ ), as proposed by Martinez et al. (1999), as well as found by Da Ros et al. (2016) when comparing sufficiency levels as a function of eucalyptus to T. ciliata (N: 25.3; P: 2.7; K: $17.7 \mathrm{~g} \mathrm{~kg}^{-1}$ ).

In relation to growth and leaf content, it is possible to verify that in the implantation phase of T. ciliata, nitrogen, phosphorus and potassium are fundamental for growth. In a study conducted with this species, Moretti et al. (2011) observed results similar to those found in the present study and state that these nutrients are limiting for the initial growth of species.

In general, the results found for T. ciliata can possibly be used as parameters/references for future studies, since little information is available in the literature for this species, and it is important to emphasize the need for future studies of a scientific nature.

\section{CONCLUSION}

The use of water retaining polymer increased the survival of $T$. ciliata seedlings, not interfering with the initial growth of plants. Additionally, for none of the evaluated characteristics, there was a significant interaction between the water retaining polymer and fertilization levels for the species.

In relation to fertilization, T. ciliata was responsive to the application of dosages of NPK, being the planting fertilization with phosphorus crucial for the initial growth of seedlings, which is maximized by the application in nitrogen and potassium in topdressing.

The fertilization with nitrogen and potassium only brings gains in the growth of $T$. ciliata seedlings if the fertilization with phosphorus was made.

\section{REFERENCES}

ALVARES, C. A.; STAPE, J. L.; SENTELHAS, P. C.; GONÇALVES, J. L. M.; SPAROVEK, G. Köppen's climate classification map for Brazil. Meteorologische Zeitschrift, Stuttgart, v. 22, n. 6, p. 711-728, 2013.

BARROS, N. F.; NOVAIS, R. F. Eucalipto. In: RIBEIRO, A. C.; GUIMARÃES, P. T. G.; ALVAREZ V., V. H. (Eds.). Recomendações para o uso de corretivos e fertilizantes em Minas Gerais: $5^{a}$ aproximação. Viçosa: CFSEMG/UFV, 1999. p.303-305.

BARROS, N. F.; NEVES, J. C. L.; NOVAIS, R. F. Recomendação de fertilizantes minerais em plantios de eucalipto. In: GONÇALVES, J. L. M.; BENEDETTI, V. Nutrição e fertilização florestal. Piracicaba: IPEF, 2005. p. 269-286.

BARTIERES, E. M. M.; CARNEVALI, N. H. S.; LIMA, E. S.; CARNEVALI, T. O.; MALLMANN, V. Hidrogel, calagem e adubação no desenvolvimento inicial, sobrevivência e composição nutricional de plantas híbridas de eucalipto.

Pesquisa Florestal Brasileira, Colombo, v. 36, n. 86, p. 145-151, 2016.

Sci. For., Piracicaba, v. 47, n. 122, p. 317-325, jun. 2019

DOI: doi.org/10.18671/scifor.v47n122.14 
Nieri et al. - Water retaining polymer and fertilization in the implantation of

Toona ciliata $\mathrm{M}$. Roemer

BERNARDI, M. R.; SPEROTTO JUNIOR, M.; DANIEL, O.; TADEU VITORINO, A. C. Crescimento de mudas de Corymbia citriodora em função do uso de hidrogel e adubação. Revista Cerne, Lavras, v. 18, n. 1, p. 67-74, 2012.

BUDOWSKI, A. Distribution of tropical American rain forest species in the light succession progress. Turrialba, San Jose, v. 15, n.1, p. 40-42, 1965.

CARVALHO, R. P.; CRUZ, M. C. M.; MARTINS, L. M. Frequência de irrigação utilizando polímero hidroabsorvente na produção de mudas de maracujazeiro-amarelo. Revista Brasileira de Fruticultura, Jaboticabal, v. 35, n. 2, p. 518-526, 2013.

DA ROS, C. O.; PERRANDO, E. R.; SOMAVILLA, L.; ENGEL, K.; PREDIGE, D. M. S. A.; SILVA, R. F.; SILVA, V. R. Crescimento inicial de povoamentos mistos de Eucalyptus grandis Hill ex Maiden e Toona ciliata M. Roem var. australis com supressão de macronutrientes primários. Scientia Forestalis, Piracicaba, v.44, n.111, p. 769-777, 2016.

MARCO, R. Resposta de mudas de Toona ciliata M. Roem à fertilização orgânica e química. Enciclopédia Biosfera, Goiânia, v. 9, n. 16, p. 1939-1946. 2013.

DRANSKI, J. A. L.; PINTO JÚNIOR, A. S.; CAMPAGNOLO, M. A.; MALAVASI, U. C.; MALAVASI, M. M.; GUIMARÃES, V. F. Sobrevivência e crescimento inicial de pinhão-manso em função da época de plantio e do uso de hidrogel. Ciência Florestal, Santa Maria, v. 23, n. 3, p. 489-498, 2013.

EMBRAPA - EMPRESA BRASILEIRA DE PESQUISA AGROPECUÁRIA. Sistema brasileiro de classificação de solos. 3. ed. Rio de Janeiro: Embrapa solos, 2013. 353 p.

FERREIRA, D. F. Sisvar: a computer statistical analysis system. Ciência e Agrotecnologia, Lavras, v. 35, n. 6, p. 1039-1042, 2011.

IDROBO, H. J.; RODRÍGUEZ, A. M.; DÍAZ ORTÍZ, J. E. Comportamiento del hidrogel en suelos arenosos. Ingeniería de Recursos Naturales y del Ambiente, Cali, v. 1, n. 9, p. 33-37, 2010.

INMET - INSTITUTO NACIONAL DE METEREOLOGIA. Chuva acumulada mensal x chuva (Normal climatológica 61-90) Lavras (MG) - para o ano. 2017. Disponível em: < http://www.inmet.gov.br/sim/ abre_graficos.php >. Acesso em: 09 de agosto de 2018.

KLEIN, D. R.; ANDRADE, M. M.; DERENGOSKI, J. A.; DUARTE, E.; KREFTA, S. M.; SILVEIRA, A. C.; BRUN, E. J. Aspectos gerais e silviculturais de Cordia americana, Aspidosperma polyneuron, Toona ciliata e Khaya spp. Revista de Ciências Agroveterinárias, Lages, v. 15, n. 2, p. 155-164. 2016.

MALAVOLTA, E. Manual de nutrição mineral de plantas. São Paulo: Agronômica Ceres, 2006. 638 p.

MARSCHNER, H. Mineral nutrition of higher plants. 3. ed. London: Academic Press, 2012. 889 p.

MARTINEZ, H. E. P.; CARVALHO, J. G.; SOUZA, R. B. In: RIBEIRO, A.C.; GUIMARÃES, P.T.G.; ALVAREZ V., V.H. (Eds.). Recomendações para o uso de corretivos e fertilizantes em Minas Gerais: $5^{\text {a }}$ aproximação. Viçosa: CFSEMG/UFV, 1999. p.143-168.

MILANI, P.; FRANÇA, D.; BALIEIRO, A.G.; FAEZ, R. Polymers and its applications in agriculture, Polímeros, São Carlos, v. 27, n. 2, p. 256-266, 2017.

MORETTI, B. S.; FURTINI NETO, A. E.; PINTO, S. I. C.; FURTINI, I. V.; MAGALHÃES, C. A. S. Crescimento e nutrição mineral de mudas de cedro australiano (Toona ciliata) sob omissão de nutrientes. Cerne, Lavras, v. 17, n. 4, p. 453-463, 2011.

MORO, L.; GATIBONI, L. C.; SIMONETE, M. A.; CASSOL, P. C.; CHAVES, D. M. Resposta de Pinus taeda com diferentes idades à fertilização mineral NPK no Planalto Sul Catarinense. Revista Brasileira de Ciência do Solo, Viçosa, v. 38, n.1, p.1181-1189, 2014.

NAVROSKI, M. C.; ARAÚJO, M. M.; CUNHA, F. S.; BERGHETTI, A. L. P.; PEREIRA, M. O. Redução da adubação e melhoria das características do substrato com o uso do hidrogel na produção de mudas de Eucalyptus dunnii Maiden. Ciência Florestal, Santa Maria, v. 26, n. 4, p. 1155-1165, 2016.

PAIVA, H. N.; JACOVINE, L. A. G.; TRINDADE, C.; RIBEIRO, G. T. Cultivo de eucalipto: implantação e manejo. Viçosa: Aprenda Fácil, 2011. 354 p. 
PETERSON, D. Hydrophilic polymers: effects anduses in the landscape. Soviet Soil Science, Moscou, v. 13, n. 4, p. 111-115, 2003.

PREVEDELLO, C. L.; BALENA, S. P. Efeitos de polímeros hidrorretentores nas propriedades físico- hídricas de dois meios porosos. Revista Brasileira de Ciência do Solo, Viçosa, v. 24, n. 2, p. 251-258, 2000.

R CORE TEAM. R: a language and environment for statistical computing. Vienna: R Foundation for Statistical Computing, 2016. Disponível em: < http://R-project.org >. Acesso em: 15 nov. 2019.

RESENDE, Á. V.D.; FURTINI NETO, A.E.; MUNIZ, J.A.; CURI, N.; FAQUIN, V. Crescimento inicial de espécies florestais de diferentes grupos sucessionais em resposta a doses de fósforo. Pesquisa Agropecuária Brasileira, Brasília, v. 34, n. 11, p. 2071-2081, 1999.

ROCHA, J. H. T.; PIETRO, M. R.; BORELLI, K.; BACKES, C.; NEVES, M. B. Produção e desenvolvimento de mudas de eucalipto em função de doses de fósforo. Revista Cerne, Lavras, v. 19, n. 4, p. 535-543. 2013.

SOUZA, C. A. M.; OLIVEIRA, R. B.; MARTINS FILHO, S.; LIMA, J. S. S. Crescimento em campo de espécies florestais em diferentes condiçõoes de adubações. Ciência Florestal, Santa Maria, v. 16, n. 3, p. 243-249, 2006.

SOUZA J. C. A. V.; BARROSO, D. G.; CARNEIRO, J. G. A. Cedro australiano (Toona ciliata). Niterói: Programa Rio Rural, 2010. 12 p. (Manual Técnico 21).

TAYLOR, K. C.; HALFACRE, R. G. The effect of hydrophylic polymer on media water retention and nutrient availability to Ligustrum lucidum. Hortculture Science, Alexandria, v. 21, n.5, p.1159-1161, 1986.

VICHIATO, M.; VICHIATO, M. R. M.; SILVA, C. R. R. Crescimento e composição mineral do porta-enxerto de tangerina cleópatra cultivado em substrato acrescido de polímero hidrorretentor Ciência e Agrotecnologia, Lavras, v. 28, n. 4, p. 748-756, 2004.

VILELA, R. Protetor de mudas florestais - solução prática para proteção de mudas florestais. 2018. Disponível em: < https://www.belavistaflorestal.com.br/protetor-de-mudas-florestais-solucao-pratica-paraprotecao-de-mudas-florestais/ >. Acesso em: 15 ago. 2018.

WERLE, R.; GARCIA, R. A.; ROSOLEM, C. A. Lixiviação de potássio em função da textura e da disponibilidade do nutriente no solo. Revista Brasileira de Ciência do Solo, Viçosa, v. 32, n. 1, p. 2297-2305, 2008.

Received: 01/24/2018

Accepted: 10/02/2018 